Article

\title{
Unique Authigenic Mineral Assemblages and Planktonic Foraminifera Reveal Dynamic Cold Seepage in the Southern South China Sea
}

\author{
Yang Zhou ${ }^{1}$, Pengfei $\mathrm{Di}^{2,3,4,5, * \mathbb{C}}$, Niu Li ${ }^{2,3,4,5}$, Fang Chen ${ }^{1}$, Xin Su ${ }^{6}$ and Jinpeng Zhang ${ }^{1}$ \\ 1 MNR Key Laboratory of Marine Mineral Resources, Guangzhou Marine Geological Survey, \\ Ministry of Natural Resources, Guangzhou, Guangdong 510075, China; zhouyang@hydz.cn (Y.Z.); \\ Zhchenfang66@21cn.com (F.C.); Jinpenggmgs@sina.com (J.Z.) \\ 2 Key Laboratory of Ocean and Marginal Sea Geology, South China Sea Institute of Oceanology, \\ Chinese Academy of Sciences, Guangzhou 510301, China; liniu@scsio.ac.cn \\ 3 Laboratory for Marine Mineral Resources, Qingdao National Laboratory for Marine Science and Technology, \\ Qingdao 266061, China \\ 4 Innovation Academy of South China Sea Ecology and Environmental Engineering, \\ Chinese Academy of Sciences, Guangzhou 510301, China \\ 5 Southern Marine Science and Engineering Guangdong Laboratory (Guangzhou), Guangzhou 511481, China \\ 6 School of Ocean Sciences, China University of Geosciences, Beijing 100083, China; xsu@cugb.edu.cn \\ * Correspondence: pfd@scsio.ac.cn; Tel.: +86-20-85292676; Fax: +86-20-85292676
}

Received: 2 February 2020; Accepted: 14 March 2020; Published: 19 March 2020

\begin{abstract}
Many cold seeps and gas hydrate areas have not been discovered beside the Beikan basin in the southern South China Sea (SCS), and their characteristics and histories also remain poorly known. Here we describe authigenic minerals and the carbon and oxygen isotopic composition of planktonic foraminifera Globigerinoides ruber from sediment core 2PC, recovered from the gas hydrate zone of the Nansha Trough, southern SCS, to elucidate its history of dynamic cold seepage. We infer that the occurrence of authigenic gypsum crystals and pyrite concretions, and anomalously negative $\delta^{13} \mathrm{C}$ values of Globigerinoides ruber, reflect paleo-methane seepage. Two major methane release events were identified, based on remarkable excursions in foraminifera $\delta^{13} \mathrm{C}$ at depths of $150-250 \mathrm{~cm}$ and $350-370 \mathrm{~cm}$. Euhedral gypsum crystals and tubular pyrite concretions co-occur with extremely negative planktonic foraminifera $\delta^{13} \mathrm{C}$ values, indicating a shift in the sulfate methane transition zone and a change in the methane flux. Our data suggest that authigenic mineral assemblages and $\delta^{13} \mathrm{C}$ values of planktonic foraminifera provide a valuable tool in elucidating the characteristics of dynamic methane seepage in a marine environment.
\end{abstract}

Keywords: authigenic gypsum; authigenic pyrite; cold seep; planktonic foraminifera; southern South China Sea

\section{Introduction}

The seepage of fluids containing methane associated with gas hydrate dissociation and free gas release is widely observed on the seafloor at a global scale [1-7]. At cold seeps, more than $80 \%$ of the methane is oxidized by pore-water sulfate in the sulfate-methane transition zone (SMTZ) in the sediment; this process is well known as the sulfate-driven anerobic oxidation of methane (AOM) is mediated by a consortium of methanotrophic archaea and sulfate-reducing bacteria (Equation (1) $\mathrm{CH}_{4}+\mathrm{SO}_{4}{ }^{2-} \rightarrow \mathrm{HS}^{-}+\mathrm{HCO}_{3}{ }^{2-}+\mathrm{H}_{2} \mathrm{O}$ ) [8-11]. Furthermore, bio-irrigation related to the activity of benthic organisms is a key control on the turnover rates of reduced and oxidized carbon and sulfur components between anoxic sediment and oxygenated bottom water [12]. 
In addition, the organic matter $\left(\mathrm{CH}_{2} \mathrm{O}\right)$ within sediments can be oxidized by pore-water sulfate via microbial sulfate reduction: the so-called organiclastic sulfate reduction (OSR, Equation (2): $2\left(\mathrm{CH}_{2} \mathrm{O}\right)+$ $\left.\mathrm{SO}_{4}{ }^{2-} \rightarrow \mathrm{H}_{2} \mathrm{~S}+2 \mathrm{HCO}_{3}{ }^{-}\right)$[13-17]. These processes can induce the precipitation of authigenic carbonate concretions, gypsum $\left(\mathrm{CaSO}_{4} \cdot 2 \mathrm{H}_{2} \mathrm{O}\right)$, and pyrite $\left(\mathrm{FeS}_{2}\right)$ within sediment [13-16].

Methane seepage activity varies temporo-spatially, leading to significant changes in sedimentary redox conditions [18,19], diagenetic conditions within seepage areas, and the composition of local microbial communities [20-28]. Even though gypsum is a classical evaporite mineral that is undersaturated in seawater, calcium sulfate minerals (e.g., gypsum and bassanite) and pyrite have been found in modern and ancient methane-seep environments (e.g., southwest African Margin, South China Sea (SCS)) $[15,17,29-36]$. Pyrite usually formed in sulfidic environments, which indicates hydrogen sulfide formed by AOM, and the precipitation of authigenic gypsum at cold seep is caused by an enrichment in sulfate derived from pyrite re-oxidation after cold seepage ceased $[12,17,29,37]$. Therefore, the occurrence of gypsum indicates the intermittent characteristics of cold seeps.

The $\delta^{13} \mathrm{C}$ composition of foraminifera is a common proxy for reconstructing changes in paleoceanographic and paleo-climate conditions, because foraminifera are sensitive to these changes and ubiquitous in marine settings [38,39]. In cold-seep areas, owing to the prokaryote food source for foraminifera and cemented authigenic carbonate or the incorporation of dissolved inorganic carbon (DIC) with negative $\mathrm{d}^{13} \mathrm{C}$ values into the shells, the foraminifera $\delta^{13} \mathrm{C}$ values can be depleted extremely in ${ }^{13} \mathrm{C}$ in the stratigraphic record, with more negative $\delta^{13} \mathrm{C}$ values $(-4 \%$ o to $-25 \%$ o) than those found in typical marine settings $\left(0<\delta^{13} \mathrm{C}<1.5 \%\right.$ o $)$ [38-49]. Hence, it can be interpreted as an indicator of methane seepages over geological time [40,41,50-62]. Furthermore, the abundances and diversities of the foraminiferal assemblages at cold seeps are generally lower than those of typical marine settings (non-seep areas) [42,43,63-66]. Several studies investigated the correlation between benthic foraminiferal communities (composition, abundance, diversity and dominant species) and hydrocarbon emissions $[43,59,67-70]$. Therefore, it is necessary to combine multiple indices to better describe the active characteristics and histories of cold seeps.

In recent years, many cold seeps have been discovered in the northern South China Sea, but active cold seeps have been found only in the Beikang basin in the southern South China Sea [71]. Therefore, besides the Beikang Basin, are cold seeps developed elsewhere, such as the Nansha Trough in the southern South China Sea? Additionally, what about the characteristics and histories of cold seeps? Here we describe the stable carbon isotopic composition of planktonic foraminifera Globigerinoides ruber and detailed microscopic observations of authigenic gypsum and pyrite in gas hydrate areas of the Nansha Trough in the southern SCS, with the aim of reconstructing methane flux at past cold seeps and their dynamic characteristics.

\section{Materials and Methods}

\subsection{Study Area}

The study area lies in the Nansha Trough at the southeastern margin of the Nansha Islands (Figure 1). The Nansha Trough is the largest trough developed along a SW-NE fault depression in the southern SCS. It has a sedimentary thickness of up to $2000 \mathrm{~m}$, and lies on the edge of the NW-SE Nansha compressional belt. It contains NE-SW normal faults, thrust faults and NW-SE secondary strike-slip faults [72]. Since the early Miocene, the trough has undergone complex processes of collisional, tensional and compressional deformation, with hydrocarbon gas formation and migration via leakage forces and transport channels [73], forming and storing rich oil and gas resources. The tectonic background of the trough is also conducive to the movement of biogenic gas to shallow layers, which provide a favorable site for the accumulation and storage of natural gas hydrate. In addition, bottom-simulating reflectors were recognized in the southern SCS, indicating gas hydrate accumulation [74]. 


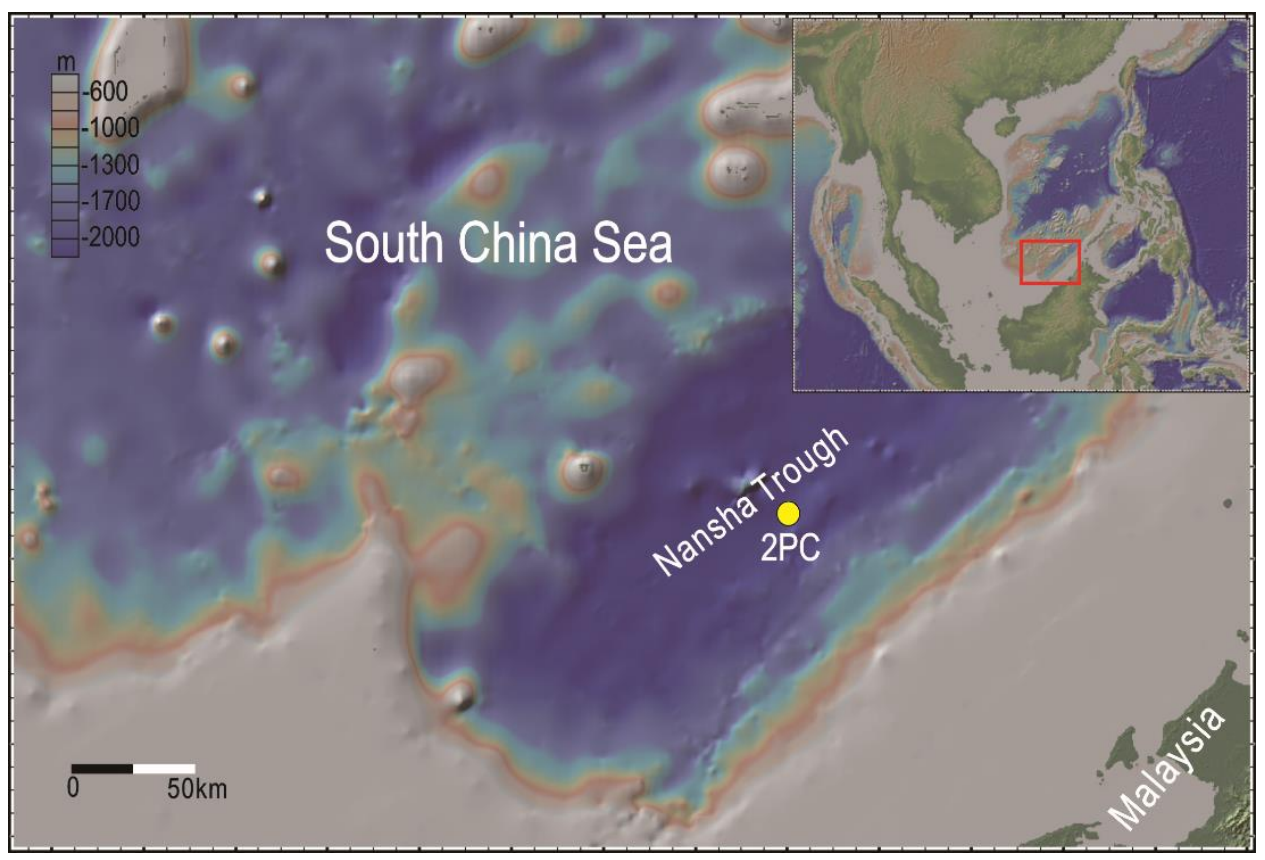

Figure 1. Maps showing the locations of the study area (red rectangle) and sediment core 2PC (yellow dot) in the southern South China Sea (SCS).

\subsection{Sampling and Analyses}

Sedimentary core 2PC, studied here, was retrieved from the Nansha trough at a water depth of $2796 \mathrm{~m}$ by the RV Haiyang-4 of the Guangzhou Marine Geological Survey, Guangzhou, China. The sediment core was $808 \mathrm{~cm}$ long, and samples were taken at $2 \mathrm{~cm}$ intervals, weighed and freeze-dried. Dry samples were weighed and wet-sieved with a mesh size of $63 \mu \mathrm{m}$ to separate carbonate, gypsum and pyrite crystals from the sediment. The remaining sediment was dried at $60{ }^{\circ} \mathrm{C}$ for carbon and oxygen isotopic analyses of planktonic foraminifera.

The gypsum and pyrite aggregates from the coarse fraction were identified using a high-power stereoscopic microscope and a Hitachi TM3030 Scanning Electron Microscope (SEM) in Energy Dispersive Spectrum (EDS) mode at the Guangzhou Marine Geological Survey, Guangzhou, China.

Stable isotopic compositions of planktonic foraminifera Globigerinoides ruber were determined after picking up a 63-250 $\mu \mathrm{m}$ fraction from the sediment and cleaning it by a standard method [75]. The first step cleans the specimens mechanically by rinsing in distilled water and reagent grade methanol repeatedly, and by washing ultrasonically to remove adhering detrital material [75]. The second step removes the organic matter by soaking the specimens in $15 \%$ hydrogen peroxide for $15 \mathrm{~min}$, followed by rinsing with methanol [75]. Globigerinoides ruber were broken using a metal probe and then treated with anhydrous phosphoric acid at $73^{\circ} \mathrm{C}$. The carbon and oxygen isotopic compositions of the foraminifera were determined using a Finnigan 253 mass spectrometer equipped with an automatic carbonate preparation device (Kiel III) at SunYat-Sen University, Guangzhou, China. Isotopic compositions were reported as an average of two analyses and normalized to Vienna Pee Dee Belemnite (VPDB), using International atomic energy agency (IAEA) reference materials 18 and 19, with standard deviations of $\pm 0.07 \%$ o for $\delta^{18} \mathrm{O}$ and $\pm 0.04 \%$ o for $\delta^{13} \mathrm{C}$. In addition, we did not analyze the benthic foraminifera due to the lack of benthic foraminifera in the sediment core $2 \mathrm{PC}$.

\section{Results}

\subsection{Morphological Characteristics of Authigenic Pyrite and Gypsum Aggregates}

Authigenic gypsum crystals and pyrite are two major authigenic minerals in sediment from core 2PC, and are found at depth intervals of 199-200, 221-222, 249-250, and 299-300 cm below 
seafloor (bsf) (Figure 2). There are also small amounts of quartz, plagioclase, K-feldspar, and so on. The morphology of authigenic gypsum and pyrite is shown in Figures 2 and 3. Pyrite may be present alone, but gypsum can only occur with pyrite in the cold seeps [33]. Gypsum is dark-yellow in color, and translucent to opaque. The dark-gray, black, or brown gypsum aggregates partly or completely enveloped pyrite (Figure 2), which is similar to that developed on the slopes of the southwest Atlantic [12]. Gypsum crystals are about 1-2 $\mathrm{mm}$ in size, are euhedral, and variable in shape with more or less prismatic or lenticular forms that are generally isolated and rarely twinned (Figure 2A-D). The gypsums are transparent, dark-yellow or dull, with etched surfaces and commonly contain inclusions of sedimentary particles. Pyrite occurs as aggregates of framboids on the surfaces of planktonic foraminifera (Figure 2E), and as micrometer-sized octahedral crystals that form tubular structures of about $10 \mathrm{~mm}$ long (Figure 2F).

SEM observations revealed that gypsum crystals are most commonly rhombic and trapezoidal in shape (Figure 3A-E), with some microcrystals occurring in radiating gypsum clusters. The individual crystals in such clusters show a range of morphologies (Figure 3A-C). Euhedral trapezoidal morphologies have enlarged $\{111\}$ and $\{110\}$ faces (Figure 3D). Clusters of gypsum crystals are commonly euhedral, with no obvious paragenetic sequence (Figure 3E).
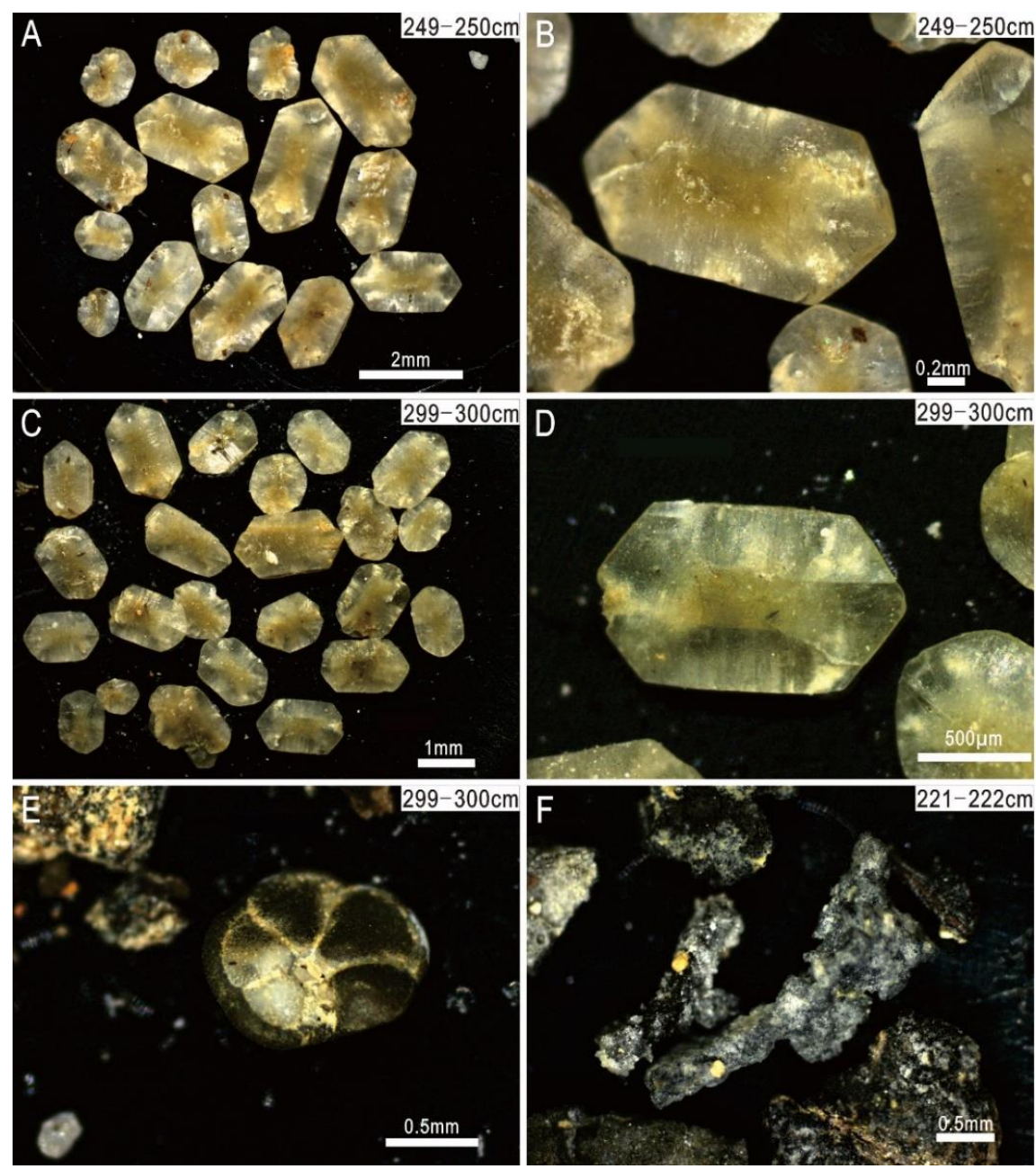

Figure 2. Microscopic observations of authigenic gypsum and pyrite. (A) Gypsum with prismatic, transparent and dull forms (249-250 cm depth); (B) prismatic gypsum crystals enclosing pyrite (249-250 cm depth); (C) prismatic, transparent and dull gypsum $(299-300 \mathrm{~cm})$; (D) prismatic gypsum crystals enclosing pyrite $(299-300 \mathrm{~cm})$; (E) A planktonic foraminifer coated with framboidal pyrite $(299-300 \mathrm{~cm}) ;(\mathbf{F})$ tubular pyrite $(221-222 \mathrm{~cm})$. 

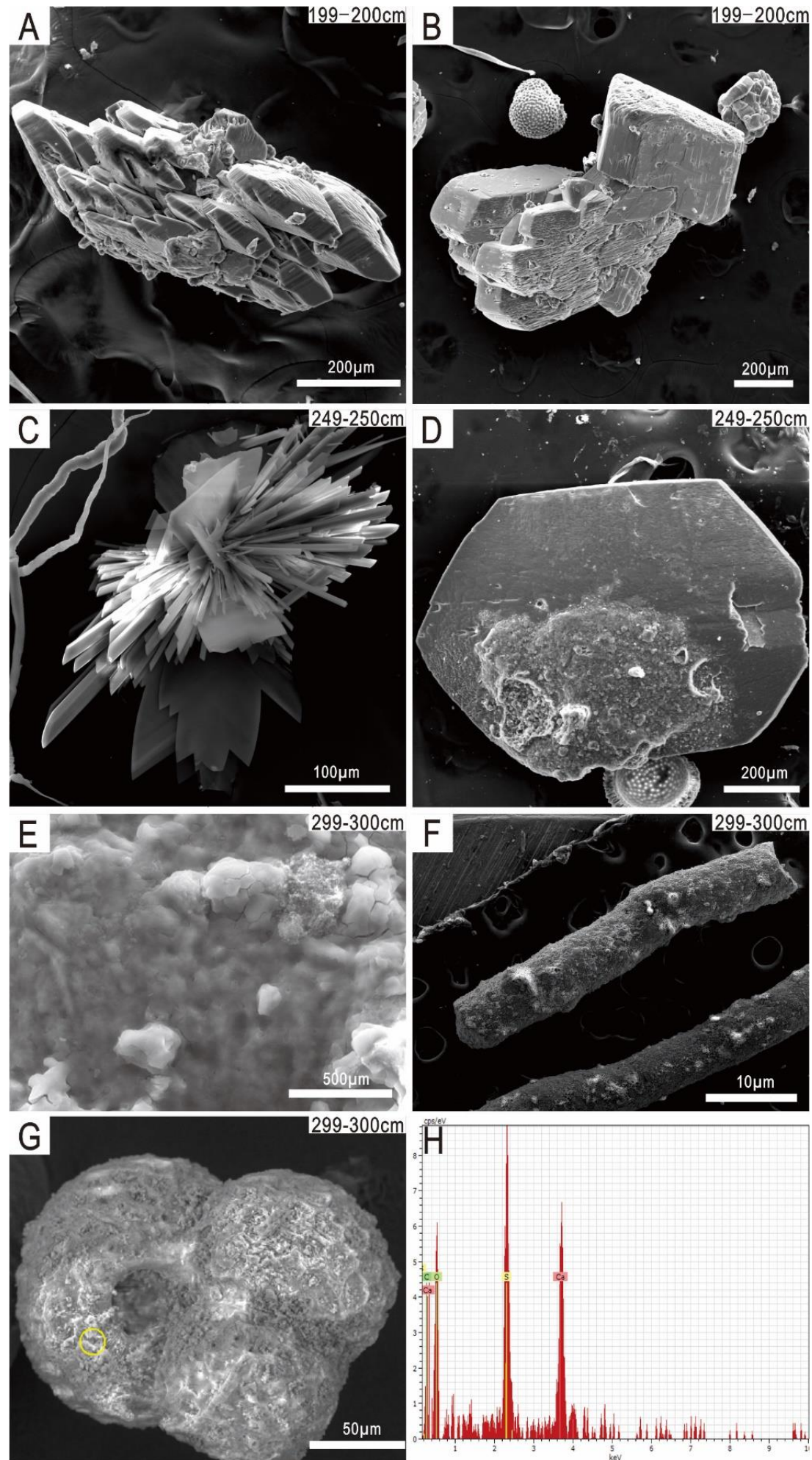

Figure 3. Scanning electron microscopy (SEM) observations and Energy Dispersive Spectrum (EDS) analysis of gypsum and pyrite aggregates from core 2PC. (A) Clusters of bladed gypsum microcrystals; (B) clusters of bladed gypsum microcrystals with framboidal pyrite; (C) clusters of bladed gypsum microcrystals; (D) gypsum crystal with trapezoidal shape and with clay minerals on its surface; (E) euhedral gypsum crystals; (F) tubular pyritized structure with secondary gypsum on its surface; (G) gypsum crystal growth on planktonic foraminifera (G. ruber); (H) EDS spectra of the gypsum indicated in $(\mathbf{G})$. 
Scanning Electron Microscopy (SEM) and Energy Dispersive Spectrum (EDS) analyses indicate that gypsum microcrystals adhere to the surface of planktonic foraminifera (Figure 3G,H). Pyrite aggregates have a black appearance, and occur in the shape of straight and irregular tubes of $\sim 40 \mu \mathrm{m}$ length, or in chambers of foraminifera tests (Figure 3F).

\subsection{Stable Isotopic Compositions of Planktonic Foraminifera}

Stable isotopic compositions (indicated by $\delta^{18} \mathrm{O}$ and $\delta^{13} \mathrm{C}$ values) of planktonic foraminifera Globigerinoides ruber are plotted against depth in Figure $4 . \delta^{13} \mathrm{C}$ values vary within a range from $-4.46 \%$ o to $+1.77 \%$, with most values being lower than those of the typical marine environment in the late Quaternary SCS [60-62]. The $\delta^{18} \mathrm{O}$ values of planktonic foraminifera generally show a trend opposite to the $\delta^{13} \mathrm{C}$ values (Figure 4), with values from $-2.91 \%$ o to $+0.27 \%$ o. Negative $\delta^{13} \mathrm{C}$ values correspond to positive $\delta^{18} \mathrm{O}$ values along the profile (Figure 4).

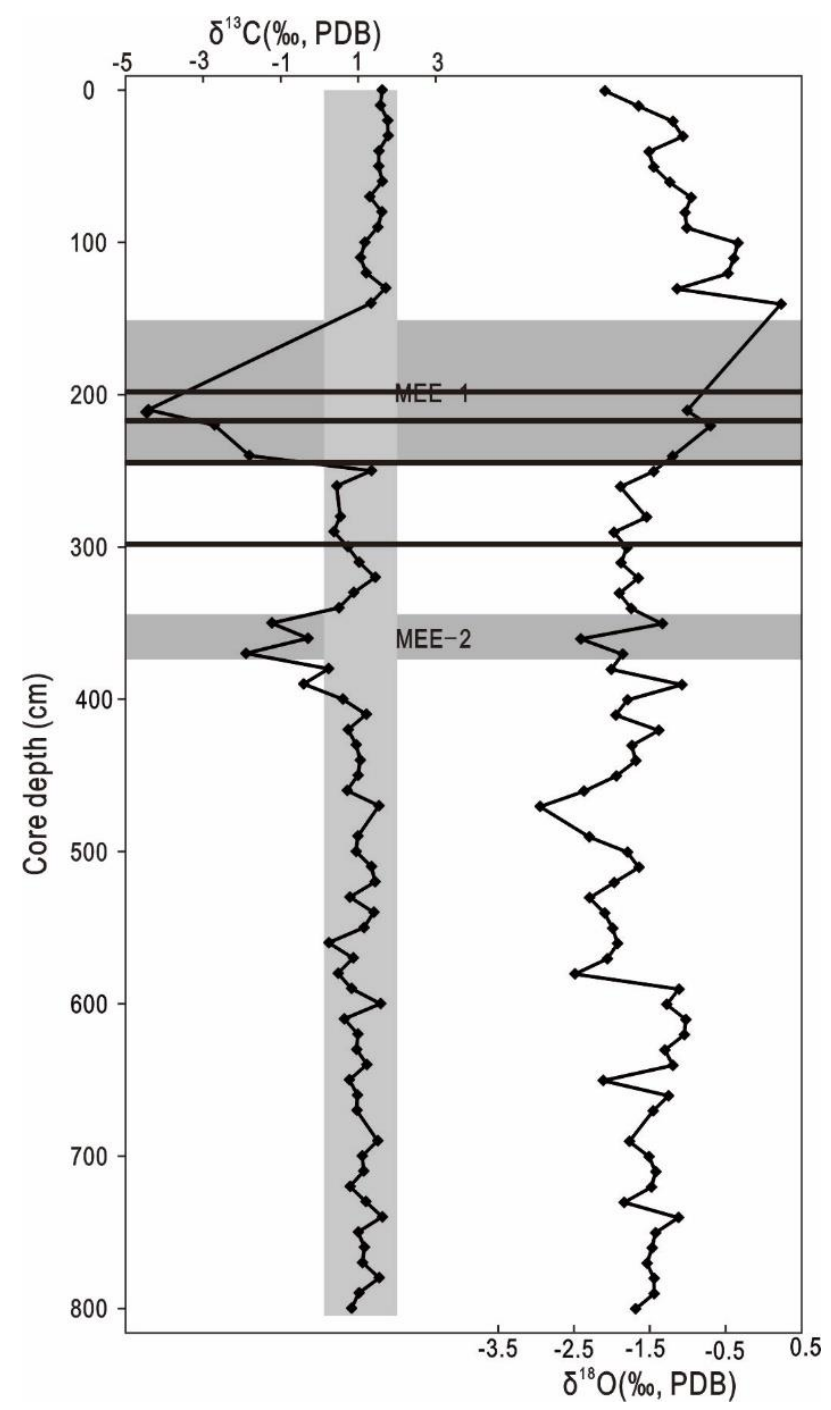

Figure 4. Stable isotopic compositions of planktonic foraminifera Globigerinoides ruber in core 2PC. Two major methane emission events (MEEs) were found. The black rectangles indicate three depth intervals of authigenic gypsum crystals and pyrite (199-200, 221-222, 249-250 and 299-300 cm bsf). The gray rectangle indicates the range of planktonic foraminifera ${ }^{13} \mathrm{C}$ of typical marine settings [60-62]. 


\section{Discussion}

\subsection{Paleo-Methane Release in the Nansha Trough}

Extreme ${ }^{13} \mathrm{C}$ depletion of planktonic and benthic foraminifera, caused by overgrowths of AOM-derived authigenic carbonate or the assimilation of methane-derived DIC produced by AOM in the sediment core, can be used as an indicator of methane emission events (MEEs) in the geological records [40,41,51-57,76]. Two major MEEs (MEE-1 and MEE-2) are evident in core 2PC, as indicated by the anomalous $\delta^{13} \mathrm{C}$ values that are well beyond the normal marine range (Figures 4 and 5). MEE-1, in the range of $150-250 \mathrm{~cm}$ bsf is characterized by a remarkable $\delta^{13} \mathrm{C}$ excursion (Figure 4), while MEE-2 is characterized by negative $\delta^{13} \mathrm{C}$ values at 350-370 $\mathrm{cm}$ bsf (Figure 4). Planktonic foraminifera negative $\delta^{13} \mathrm{C}$ values correspond to the negative $\delta^{13} \mathrm{C}$ of sediment DIC at the same depth, indicating that planktonic foraminifera shells inherit the negative $\delta^{13} \mathrm{C}$ values of authigenic carbonate cementation. In addition, the positive $\delta^{18} \mathrm{O}$ excursions of planktonic foraminifera may be affected by several reasons, such as gas hydrate decomposition [52], higher $\delta^{18} \mathrm{O}$ value of the sediment pore water where the carbonate rocks formed than that of the surface seawater [44], or the low temperature of the bottom seawater [77]. Overall, our $\delta^{13} \mathrm{C}$ isotopic records of planktonic foraminifera in core $2 \mathrm{PC}$ reveal that the two major MEEs may have distinct characteristics in terms of timing, duration and intensity.

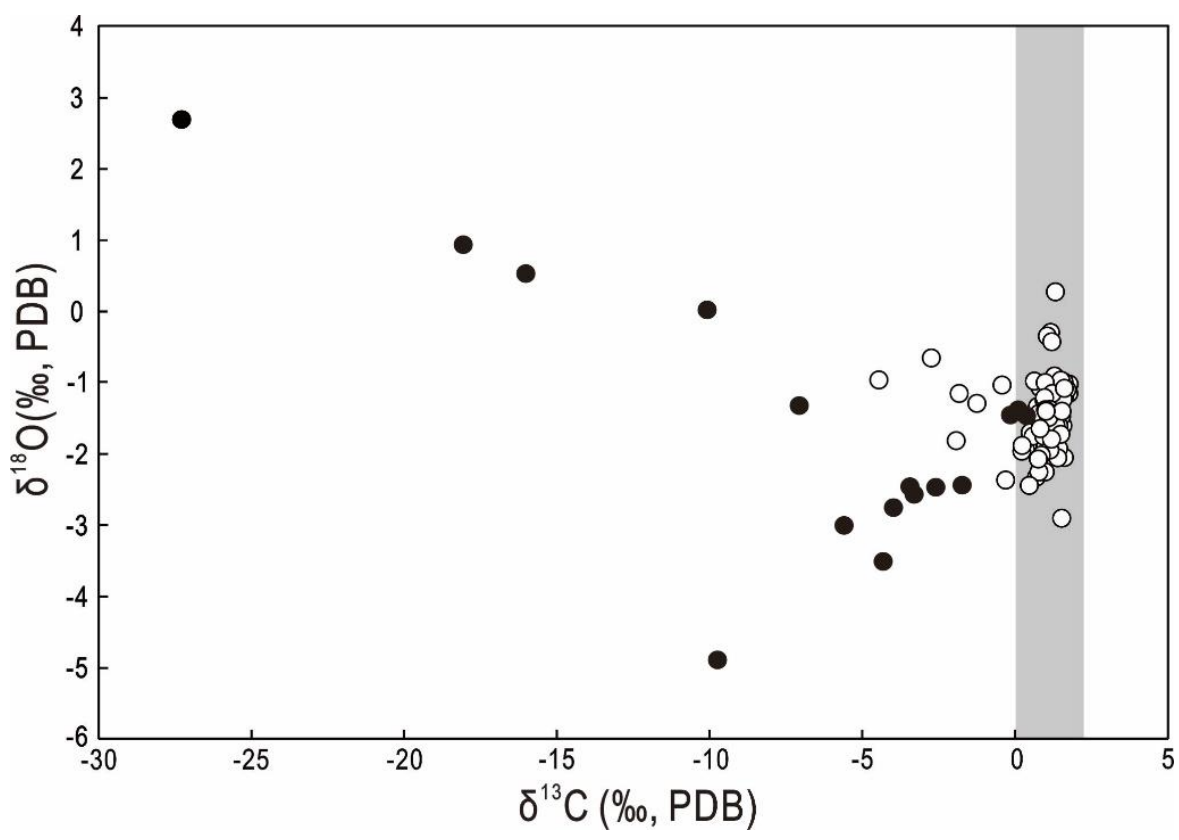

Figure 5. $\delta^{13} \mathrm{C}$ vs. $\delta^{18} \mathrm{O}$ diagram for planktonic foraminifera Globigerinoides ruber and sediment inorganic carbon. The white circles represent the stable isotopic records of planktonic foraminifera from core 2PC; black circles represent the stable isotopic records of sediment inorganic carbon from the core [78]. The gray rectangle indicates the range of planktonic foraminifera Globigerinoides ruber $\delta^{13} \mathrm{C}$ values of typical marine settings of the South China Sea [60,62].

\subsection{Authigenic Gypsum and Pyrite as Indicators of the Paleo-SMTZ}

Although seawater is largely undersaturated with respect to gypsum, it is the most common source of $\mathrm{Ca}^{2+}$ and $\mathrm{SO}_{4}{ }^{2-}$, which combine to form gypsum when saturation is reached [79]. In modern marine sediment environments with a lack of evaporation of pore fluids, the only way to achieve gypsum saturation is to add $\mathrm{Ca}^{2+}$ and/or $\mathrm{SO}_{4}{ }^{2-}$ ions to pore water [79], with several possible sources of $\mathrm{Ca}^{2+}$ and $\mathrm{SO}_{4}{ }^{2-}$ ions being available [17]. The most straightforward source is brine fluid arising from the dissolution of evaporite deposits, as in the Eastern Mediterranean [80] and Gulf of Mexico [81]. 
Another is the alteration of volcanic material, which increases the concentration of $\mathrm{Ca}^{2+}$ in pore solutions to supersaturation levels.

In a methane-rich, cold-seep environment, biogeochemical processes that control the cycling of reduced and oxidized carbon and sulfur components can significantly increase pore-water $\mathrm{SO}_{4}{ }^{2-}$ concentrations to enable the precipitation and dissolution of authigenic minerals in anoxic sediment. Examples include the oxidation of sedimentary sulfide minerals [82], the anerobic re-oxidation of authigenic sulfides [83], and the disproportionation reactions of sulfide oxidation intermediates $[84,85]$ in interstitial waters, as observed in the porewaters of a giant cold-water coral mounds on the Pen Duick Escarpment, Gulf of Cadiz [30,85]. The dissolution of calcium carbonate minerals (calcite or aragonite) precipitated by AOM or the oxidation of sulfide can also increase $\mathrm{Ca}^{2+}$ concentrations in pore-water $[15,17,30,86]$.

The morphology of gypsum crystals in core 2PC indicates an authigenic origin. Differences in the crystal morphology of authigenic gypsum may be controlled by precipitation rates or chemical variations in the pore-water environment [86-88]. In SEM and stereoscopic images, all gypsum crystals appear euhedral, with sizes of a few millimeters and smooth surfaces (Figures 2 and 3), suggesting in-situ formation in a burial setting, similar to authigenic gypsum in the northern South China Sea and the southwest African Margin [12,17]. Furthermore, gypsum encloses pyrite (Figure 2), indicating its formation was related to the oxidation or re-oxidation of sedimentary sulfide minerals. Therefore, the presence of gypsum in the sediment core indicates the intermittency of cold seeps and the dynamic characteristics of methane activity.

Sedimentary pyrite is generated from dissolved sulfide ions reacting with reactive detrital iron minerals [89], as in the northern Gulf of Mexico continental slope [32]. The formation of tubular pyrite is related to hydrogen sulfide diffusion in sediments, bioturbation, or tubeworms in the sediment $[16,17,90]$. Framboids including tube pyrite in core 2PC were generated from sulfide ions in the pore-water by rapid nucleation and crystal growth via the pyrite precursors mackinawite (FeS) or greigite $\left(\mathrm{Fe}_{3} \mathrm{~S}_{4}\right)[16,89-94]$.

Euhedral gypsum crystals are usually produced directly from supersaturated solutions in hypersulfidic and anoxic conditions within the sediment [7]. Authigenic gypsum is abundant in three intervals (221-222, 249-250 and 299-300 cm bsf), each of which is also a pyrite enrichment zone (Figure 4). Furthermore, the enrichment zones of authigenic gypsum and pyrite correspond to extreme ${ }^{13} \mathrm{C}$ depletions of planktonic foraminifera, indicating that gypsum is only formed after pyrite is formed, and the establishment of more oxidizing conditions, probably caused by waning seepage [17]. However, no gypsum or pyrite occurs at $350-370 \mathrm{~cm}$ bsf, although the negative $\delta^{13} \mathrm{C}$ value of planktonic foraminifera is beyond the normal marine range. The occurrence of authigenic gypsum in the sediment core thus indicates that the past methane-releasing events ceased.

\section{Conclusions}

In this study, authigenic minerals (gypsum and pyrite) and stable carbon and oxygen isotopes of planktonic foraminifera from cold-seep sediments of the Nansha Trough were used to identify dynamic methane-release events. Two extremely negative $\delta^{13} \mathrm{C}$ values of planktonic foraminifera, lower than those of the typical marine environment, were found in sediment core $2 \mathrm{PC}$. Such anomalous $\delta^{13} \mathrm{C}$ values are caused by the assimilation of methane-derived DIC produced by AOM with a very low $\delta^{13} \mathrm{C}$ signature, which can be interpreted as representing historic MEEs. Authigenic gypsum and pyrite occur at three levels in core 2PC, and are the products of biogeochemical redox reactions. Their profile positions correspond to those of the extremely negative $\delta^{13} \mathrm{C}$ values of planktonic foraminifera, indicating that the decreased methane-release flux can cause the SMTZ to migrate downward. MEE-1, characterized by extreme ${ }^{13} \mathrm{C}$ depletion relative to MEE-2, is likely the stronger and longer-lasting MEE. Overall, our results provide evidence of dynamic methane emissions, with the depth of the SMTZ and methane-emission fluxes varying in the past. 
Author Contributions: Conceptualization: P.D. and N.L.; methodology: Y.Z., X.S., F.C., J.Z. and N.L.; formal analysis: Y.Z.; investigation: P.D. and N.L.; resources: Y.Z. and N.L.; data curation: Y.Z., P.D. and N.L.; writing-original draft preparation: Y.Z. and P.D.; writing — review and editing: P.D. and N.L.; project administration: P.D. and N.L.; funding acquisition: Y.Z., P.D. and N.L. All authors have read and agreed to the published version of the manuscript.

Funding: This study was partially supported by the National Key R\&D Program of China (2018YFC0310004), the National Natural Science Foundation of China (41506065, 41706053, 41676046, 41976061), the Qingdao National Laboratory for Marine Science and Technology (QNLM2016ORP0204), the Guangdong Basic and Applied Basic Research Foundation (2019A1515011809) and the Key Special Project for Introduced Talents Team of Southern Marine Science and Engineering Guangdong Laboratory (Guangzhou) (GML2019ZD0104).

Acknowledgments: We thank the crew of the research vessel Haiyang-04 for their support at sea.

Conflicts of Interest: The authors declare no conflict of interest.

\section{References}

1. Suess, E.; Torres, M.E.; Bohrmann, G.; Collier, R.W.; Greinert, J.; Linke, P.; Rehder, G.; Tréhu, A.; Wallmann, K.; Winckler, G.; et al. Gas hydrate destabilization: Enhanced dewatering, benthic material turnover and large methane plumes at the Cascadia convergent margin. Earth Planet. Sci. Lett. 1999, 170,1-15. [CrossRef]

2. Judd, A.G. The global importance and context of methane escape from the seabed. Geo-Mar. Lett. 2003, 23, 147-154. [CrossRef]

3. Judd, A.G.; Hovland, M.; Dimitrov, L.I.; Garcia Gil, S.; Jukes, V. The geological methane budget at continental margins and its influence on climate change. Geofluids 2002, 2, 109-126. [CrossRef]

4. Torres, M.E.; McManus, J.; Hammond, D.E.; de Angelis, M.A.; Heeschen, K.U.; Colbert, S.L.; Tryon, M.D.; Brown, K.M.; Suess, E. Fluid and chemical fluxes in and out of sediments hosting methane hydrate deposits on Hydrate Ridge, OR, I: Hydrological provinces. Earth Planet. Sci. Lett. 2002, 201, 525-540. [CrossRef]

5. Campbell, K.A. Hydrocarbon seep and hydrothermal vent paleoenvironments and paleontology: Past developments and future research directions. Palaeogeogr. Palaeoclimatol. Palaeoecol. 2006, 232, $362-407$. [CrossRef]

6. Judd, A.G.; Hovland, M. Seabed Fluid Flow: The Impact of Geology, Biology and the Marine Environment; Cambridge University Press: Cambridge, UK, 2007.

7. Boetius, A.; Wenzhöfer, F. Seafloor oxygen consumption fuelled by methane from cold seeps. Nat. Geosci. 2013, 6, 725-734. [CrossRef]

8. Hinrichs, K.-U.; Hayes, J.M.; Sylva, S.P.; Brewer, P.G.; DeLong, E.F. Methane-consuming archaebacteria in marine sediments. Nature 1999, 398, 802-805. [CrossRef]

9. Boetius, A.; Ravenschlag, K.; Schubert, C.J.; Rickert, D.; Widdel, F.; Gieseke, A.; Amann, G.; Jørgensen, B.B.; Witte, U.; Pfannkuche, O. A marine microbial consortium apparently mediating anaerobic oxidation of methane. Nature 2000, 407, 623-626. [CrossRef]

10. Orphan, V.J.; House, C.H.; Hinrichs, K.-U.; McKeegan, K.D.; DeLong, E.F. Methane-consuming archaea revealed by directly coupled isotopic and phylogenetic analysis. Science 2001, 293, 484-487. [CrossRef]

11. Reeburgh, W.S. Oceanic methane biogeochemistry. Chem. Rev. 2007, 107, 486-513. [CrossRef]

12. Pierre, C. Origin of the authigenic gypsum and pyrite from active methane seeps of the southwest African Margin. Chem. Geol. 2017, 449, 158-164. [CrossRef]

13. Peckmann, J.; Reimer, A.; Luth, U.; Luth, C.; Hansen, B.T.; Heinicke, C.; Hoefs, J.; Reitner, J. Methane-derived carbonates and authigenic pyrite from the northwestern Black Sea. Mar. Geol. 2001, 177, 129-150. [CrossRef]

14. Lim, Y.C.; Lin, S.; Yang, T.F.; Chen, Y.; Liu, C. Variations of methane induced pyrite formation in the accretionary wedge sediments offshore southwestern Taiwan. Mar. Petrol. Geol. 2011, 28, 1829-1837. [CrossRef]

15. Pierre, C.; Blanc-Valleron, M.M.; Demange, J.; Boudouma, O.; Foucher, J.P.; Pape, T.; Himmler, T.; Fekete, N.; Spiess, V. Authigenic carbonates from active methane seeps offshore southwest Africa. Geo-Mar. Lett. 2012, 32, 501-513. [CrossRef]

16. Zhang, M.; Konishi, H.; Xu, H.F.; Sun, X.M.; Lu, H.F.; Wu, D.D.; Wu, N.Y. Morphology and formation mechanism of pyrite induced by the anaerobic oxidation of methane from the continental slope of the NE South China Sea. J. Asian Earth Sci. 2014, 92, 293-301. [CrossRef]

17. Lin, Z.; Sun, X.; Lu, Y.; Xu, L.; Gong, J.; Lu, H.; Teichert, B.M.A.; Peckmann, J. Stable isotope patterns of coexisting pyrite and gypsum indicating variable methane flow at a seep site of the Shenhu area, South China Sea. J. Asian Earth Sci. 2016, 123, 213-223. [CrossRef] 
18. Tryon, M.D.; Brown, K.M. Fluid and chemical cycling at Bush Hill: Implications for gas- and hydrate-rich environments. Geochem. Geophys. Geosyst. 2004, 5, 1-7. [CrossRef]

19. Solomon, E.A.; Kastner, M.; Jannasch, H.; Robertson, G.; Weinstein, Y. Dynamic fluid flow and chemical fluxes associated with a seafloor gas hydrate deposit on the northern Gulf of Mexico slope. Earth Planet. Sci. Lett. 2008, 270, 95-105. [CrossRef]

20. Teichert, B.M.A.; Eisenhauer, A.; Bohrmann, G.; Haase-Schramm, A.; Bock, B.; Linke, P. U/Th systematics and ages of authigenic carbonates from Hydrate Ridge, Cascadia Margin: Recorders of fluid flow variations. Geochim. Cosmochim. Acta 2003, 67, 3845-3857. [CrossRef]

21. Bhatnagar, G.; Chapman, W.G.; Dickens, G.R.; Dugan, B.; Hirasaki, G.J. Sulfate methane transition as a proxy for average methane hydrate saturation in marine sediments. Geophys. Res. Lett. 2008, 35, 1-15. [CrossRef]

22. Feng, D.; Chen, D.; Peckmann, J. Rare earth elements in seep carbonates as tracers of variable redox conditions at ancient hydrocarbon seeps. Terra Nova 2009, 21, 49-56. [CrossRef]

23. Feng, D.; Birgel, D.; Peckmann, J.; Roberts, H.H.; Joye, S.B.; Sassen, R.; Liu, X.-L.; Hinrichs, K.-U.; Chen, D. Time integrated variation of sources of fluids and seepage dynamics archived in authigenic carbonates from Gulf of Mexico Gas Hydrate Seafloor Observatory. Chem. Geol. 2014, 385, 129-139. [CrossRef]

24. Birgel, D.; Feng, D.; Roberts, H.H.; Peckmann, J. Changing redox conditions at cold seeps as revealed by authigenic carbonates from Alaminos Canyon, northern Gulf of Mexico. Chem. Geol. 2011, 285, 82-96. [CrossRef]

25. Himmler, T.; Bach, W.; Bohrmann, G.; Peckmann, J. Rare earth elements in authigenic methane-seep carbonates as tracers for fluid composition during early diagenesis. Chem. Geol. 2010, 277, 126-136. [CrossRef]

26. Himmler, T.; Haley, B.A.; Torres, M.E.; Klinkhammer, G.P.; Bohrmann, G.; Peckmann, J. Rare earth element geochemistry in cold-seep pore waters of Hydrate Ridge, northeast Pacific Ocean. Geo-Mar. Lett. 2013, 33, 369-379. [CrossRef]

27. Hu, Y.; Feng, D.; Peckmann, J.; Roberts, H.H.; Chen, D. New insights into cerium anomalies and mechanisms of trace metal enrichment in authigenic carbonate from hydrocarbon seeps. Chem. Geol. 2014, 381, 55-66. [CrossRef]

28. Hu, Y.; Feng, D.; Chen, L.; Zheng, G.; Peckmann, J.; Chen, D. Using iron speciation in authigenic carbonates from hydrocarbon seeps to trace variable redox conditions. Mar. Petrol. Geol. 2015, 67, 111-119. [CrossRef]

29. Crémière, A.; Pierre, C.; Blanc-Valleron, M.M.; Zitter, T.; Cagatay, N.M.; Henry, P. Methane-derived authigenic carbonates along the North Anatolian fault system in the Sea of Marmara (Turkey). Deep Sea Res. Part I: Oceanogr. Res. Pap. 2012, 66, 114-130. [CrossRef]

30. Peckmann, J.; Goedert, J.L.; Heinrichs, T.; Hoefs, J.; Reitner, J. The Late Eocene 'Whiskey Creek' methane-seep deposit (western Washington State)-Part II: Petrology, stable isotopes, and biogeochemistry. Facies 2003, 48, 241-254. [CrossRef]

31. Sassen, R.; Roberts, H.H.; Carney, R.; Milkov, A.V.; DeFreitas, D.A.; Lanoil, B.; Zhang, C.L. Free hydrocarbon gas, gas hydrate, and authigenic minerals in chemosynthetic communities of the northern Gulf of Mexico continental slope: Relation to microbial processes. Chem. Geol. 2004, 205, 195-217. [CrossRef]

32. Wang, J.; Suess, E.; Rickert, D. Authigenic gypsum found in gas hydrate associated sediments from Hydrate Ridge, the eastern North Pacific. Sci. China Ser. D Earth Sci. 2004, 47, 280-288. [CrossRef]

33. Chen, Z.; Yan, W.; Chen, M.H.; Lu, J.; Gu, S.C. Formation of authigenic gypsum and pyrite assemblage and its siganificance to gas ventings in Nansha Trough, South China Sea. Mar. Geol. Quarter. Geol. 2007, 2, 91-100.

34. Larrasoaña, J.C.; Roberts, A.P.; Musgrave, R.J.; Gràcia, E.; Piñero, E.; Vega, M.; Martínez-Ruiz, F. Diagenetic formation of greigite and pyrrhotite in gas hydrate marine sedimentary systems. Earth Planet. Sci. Lett. 2007, 261, 350-366. [CrossRef]

35. Bayon, G.; Birot, D.; Ruffine, L.; Caprais, J.-C.; Ponzevera, E.; Bollinger, C.; Donval, J.-P.; Charlou, J.-L.; Voisset, M.; Grimaud, S. Evidence for intense REE scavenging at cold seeps from the Niger Delta margin. Earth Planet. Sci. Lett. 2011, 312, 443-452. [CrossRef]

36. Kocherla, M. Authigenic gypsum in gas hydrate associated sediments from the east coast of India (Bay of Bengal). Acta Geol. Sin. 2013, 87, 749-760. [CrossRef]

37. Pirlet, H.; Wehrmann, L.M.; Brunner, B.; Frank, N.; Dewanckele, J.; Van Rooij, D.; Foubert, A.; Swennen, R.; Naudts, L.; Boone, M.; et al. Diagenetic formation of gypsum and dolomite in a cold-water coral mound in the Porcupine Seabight, off Ireland. Sedimentology 2010, 57, 786-805. [CrossRef] 
38. Gooday, A.J. Benthic foraminifera (Protista) as tools in deep-water palaeoceanography: Environmental influences on faunal characteristics. Adv. Mar. Biol. 2003, 46, 1-90.

39. Jorissen, F.J.; Fontanier, C.; Thomas, E. Paleoceanographical proxies based on deep-sea benthic foraminiferal assemblage characteristics. In Proxies in Late Cenozoic Paleoceanography; Elsevier: Amsterdam, The Netherlands, 2007; Volume 1, 862p.

40. Wefer, G.; Heinze, P.M.; Berger, W.H. Clues to ancient methane release. Nature 1994, 369, 282. [CrossRef]

41. Panieri, G.; Camerlenghi, A.; Conti, S.; Pini, G.A.; Cacho, I. Methane seepages recorded in benthic foraminifera from Miocene seep carbonates, Northern Apennines (Italy). Palaeogeogr. Palaeoclimatol. Palaeoecol. 2009, 284, 271-282. [CrossRef]

42. Fontanier, C.; Koho, K.A.; Goni-Urriza, M.S.; Deflandre, B.; Galaup, S.; Ivanovsky, A.; Gayet, N.; Dennielou, B.; Gremare, A.; Bichon, S.; et al. Benthic foraminifera from the deep-water Niger Delta (Gulf of Guinea): Assessing present-day and past activity of hydrate pockmarks. Deep-Sea Res. Part I 2014, 94, 87-106. [CrossRef]

43. Panieri, G.; James, R.H.; Camerlenghi, A.; Westbrook, G.K.; Consolaro, C.; Cacho, I.; Cesari, V.; Cervera, C.S. Record of methane emissions from the West Svalbard continental margin during the last 23.500 yrs revealed by ${ }^{13} \mathrm{C}$ of benthic foraminifera. Global Planet. Chang. 2014, 122, 151-160. [CrossRef]

44. Hill, T.M.; Kennett, J.P.; Valentine, D.L. Isotopic evidence for the incorporation of methane-derived carbon into foraminifera from modern methane seeps, Hydrate Ridge, Northeast Pacific. Geochim. Cosmochim. Acta 2004, 68, 4619-4627. [CrossRef]

45. Hinrichs, K.U.; Hmelo, L.R.; Sylva, S.P. Molecular fossil record of elevated methane levels in late Pleistocene coastal waters. Science 2003, 299, 1214-1217. [CrossRef] [PubMed]

46. Keigwin, L.D. Late Pleistocene-Holocene paleoceanography and ventilation of the Gulf of California. J. Oceanogr. 2002, 58, 421-432. [CrossRef]

47. Kennett, J.P.; Cannariato, K.G.; Hendy, I.L.; Behl, R.J. Carbon isotopic evidence for methane hydrate instability during Quaternary interstadials. Science 2000, 88, 128-133. [CrossRef]

48. Mackensen, A.; Wollenburg, J.; Licari, L. Low $\delta^{13} \mathrm{C}$ in tests of live epibenthic and endobenthic foraminifera at a site of active methane seepage. Paleoceanography 2006, 21. [CrossRef]

49. Ohkushi, K.; Ahagon, N.; Uchida, M.; Shibata, Y. Foraminiferal isotope anomalies from northwestern Pacific marginal sediments. Geochem. Geophys. Geosyst. 2005, 6. [CrossRef]

50. Uchida, M.; Ohkushi, K.; Kimoto, K.; Inagaki, F.; Ishimura, T.; Tsunogai, U.; TuZino, T.; Shibata, Y. Radiocarbon-based carbon source quantification of anomalous isotopic foraminifera in last glacial sediments in the western North Pacific. Geochem. Geophys. Geosyst. 2008, 9. [CrossRef]

51. Katz, M.E.; Pak, D.K.; Dickens, G.R.; Miller, K.G. The source and fate of massive carbon input during the latest Paleocene thermal maximum. Science 1999, 286, 1531-1533. [CrossRef]

52. Hesselbo, S.P.; Grocke, D.R.; Jenkyns, H.C.; Bjerrum, C.J.; Farrimond, P.; Morgans Bell, H.S.; Green, O.R. Massive dissociation of gas hydrate during a Jurassic oceanic anoxic event. Nature 2000, 406, 392-395. [CrossRef]

53. Jahren, A.H.; Arens, N.C.; Sarmiento, G.; Guerrero, J.; Amundson, R. Terrestrial record of methane hydrate dissociation in the Early Cretaceous. Geology 2001, 29, 159-162. [CrossRef]

54. Padden, M.; Weissert, H.; de Rafelis, M. Evidence for Late Jurassic release of methane from gas hydrate. Geology 2001, 29, 223-226. [CrossRef]

55. Rathburn, A.E.; Pérez, M.E.; Martin, J.B.; Day, S.A.; Mahn, C.; Gieskes, J.; Ziebis, W.; Williams, D.; Bahls, A. Relationships between the distribution and stable isotopic composition of living benthic foraminifera and cold methane seep biogeochemistry in Monterey Bay, California. Geochem. Geophys. Geosyst. 2003, 4, 1106. [CrossRef]

56. Panieri, G. Benthic foraminifera associated with a hydrocarbon seep in the Rockall Trough (NE Atlantic). Geobios 2005, 38, 247-255.

57. Panieri, G.; Camerlenghi, A.; Cacho, I.; Cervera, C.S.; Canals, M.; Lafuerza, S.; Herrera, G. Tracing seafloor methane emissions with benthic foraminifera: Results from the Ana submarine landslide (Eivissa Channel, Western Mediterranean Sea). Mar. Geol. 2012, 291-294, 97-112. [CrossRef]

58. Panieri, G.; Graves, C.A.; James, R.H. Paleo-methane emissions recorded in foraminifera near the landward limit of the gas hydrate stability zone offshore western Svalbard. Geochem. Geophys. Geosyst. 2016, 17, 521-537. [CrossRef] 
59. Bernhard, J.M.; Buck, K.R.; Barry, J.P. Monterey Bay cold-seep biota: Assemblages, abundance, and ultrastructure of living foraminifera. Deep Sea Res. Part I: Oceanogr. Res. Pap. 2001, 48, 2233-2249.

60. Sibuet, M.; Olu, K. Biogeography, biodiversity and fluid dependence of deep-sea cold-seep communities at active and passive margins. Deep-Sea Res. Part II 1998, 45, 517-567. [CrossRef]

61. Qian, J.X. Paleoceanography for the Late Quaternary in the South China Sea; China Science Press: Beijing, China, 1999; pp. 39-55.

62. Jian, Z.; Wang, L. Late quaternary benthic foraminifera and deep-water paleoceanography in the South China Sea. Mar. Micropaleontol. 1997, 32, 127-154. [CrossRef]

63. Jian, Z.; Zhao, Q.; Cheng, X.; Wang, J.; Wang, P.; Su, X. Pliocene-Pleistocene stable isotope and paleoceanographic changes in the northern South China Sea. Palaeogeogr. Palaeoclimatol. Palaeoecol. 2003, 193, 425-442. [CrossRef]

64. Formolo, M.J.; Lyons, T.W.; Zhang, C.L.; Kelley, C.A.; Sassen, R.; Horita, J.; Cole, D.R. Quantifying carbon sources in the formation of authigenic carbonates at gas hydrate sites in the Gulf of Mexico. Chem. Geol. 2004, 205, 253-264. [CrossRef]

65. Heinz, P.; Sommer, S.; Pfannkuche, O.; Hemleben, C. Living benthic foraminifera in sediments influenced by gas hydrates at the Cascadia convergent margin, NE Pacific. Mar. Ecol. Prog. Ser. 2005, 304, 77-89. [CrossRef]

66. Rathburn, A.E.; Levin, L.A.; Tryon, M.; Gieskes, J.M.; Martin, J.M.; Perez, M.E.; Fodrie, F.J.; Neira, C.; Fryer, G.J.; Mendoza, G.; et al. Geological and biological heterogeneity of the Aleutian margin (1965-4822 m). Prog. Oceanogr. 2009, 80, 22-50. [CrossRef]

67. Panieri, G. Benthic foraminifera response to methane release in an Adriatic Sea pockmark. Riv. Ital. Paleontol. E Stratigr. 2003, 109, 549-562.

68. Rathburn, A.E.; Levin, L.A.; Held, Z.; Lohmann, K.C. Benthic foraminifera associated with cold methane seeps on the northern California margin: Ecology and stable isotopic composition. Mar. Micropaleontol. 2000, 38, 247-266. [CrossRef]

69. Sen Gupta, B.K.; Platon, E.; Bernhard, J.M.; Aharon, P. Foraminiferal colonization of hydrocarbon-seep bacterial mats and underlying sediment, Gulf of Mexico slope. J. Foraminifer. Res. 1997, 27, 292-300. [CrossRef]

70. Torres, M.E.; Mix, A.C.; Kinports, K.; Haley, B.A.; Klinkhammer, G.P.; Mcmanus, J.; De Angelis, M. Is methane venting at the seafloor recorded by $\delta^{13} \mathrm{C}$ of benthic foraminifera shells? Paleoceanography 2003, 18. [CrossRef]

71. Li, N.; Yang., X.; Peng., J.; Zhou., Q.; Chen., D. Paleo-cold seep activity in the southern South China Sea: Evidence from the geochemical and geophysical records of sediments. J. Asian Earth Sci. 2018, 168, 106-111. [CrossRef]

72. Liu, H.; Yan, P.; Sun, Y. Layer-block tectonics of the Nansha microplate. Geol. China 2002, 29, 374-381.

73. Ingram, G.M.; Chisholm, T.J.; Grant, C.J.; Hedlund, C.A.; Stuart-Smith, P.; Teasdale, J. Deepwater North West Borneo: Hydrocarbon accumulation in an active fold and thrust belt. Mar. Petrol. Geol. 2004, 21, 879-887. [CrossRef]

74. Berner, U.; Faber, E. Hydrocarbon gases in surface sediments of the South China Sea. In Marine Geology and Geophysics of the South China Sea; Jin, X.L., Ed.; China Ocean Press: Beijing, China, 1990; pp. 199-211.

75. Cheng, X.; Huang, B.; Jian, Z.; Zhao, Q.; Tian, J.; Li, J. Foraminiferal isotopic evidence for monsoonal activity in the South China Sea: A present-LGM comparison. Mar. Micropaleontol. 2005, 54, 125-139. [CrossRef]

76. Wan, S.; Feng, D.; Chen, F.; Zhuang, C.; Chen, D. Foraminifera from gas hydrate-bearing sediments of the northeastern South China Sea: Proxy evaluation and application for methane release activity. J. Asian Earth Sci. 2018, 168, 125-136. [CrossRef]

77. Martinson, D.G.; Pisias, N.G.; Hays, J.D.; Imbrie, J.; Moore, T.C.; Shachleton, N.J. Age Dating and the Orbital Theory of the Ice Ages: Development of a High-Resolution 0 to 300,000 Year Chronostratigraghy. Quat. Res. 1987, 27, 1-29. [CrossRef]

78. Li, N.; Di, P.; Feng, D.; Chen, D. Persistent deep-water oxygen depletion caused by methane seepage during the last glacial maximum: Evidence from the South China Sea. Ore Geol. Rev. 2020, submitted.

79. Hoareau, G.; Monnin, C.; Odonne, F. The stability of gypsum in marine sediments using the entire ODP/IODP porewater composition database. Mar. Geol. 2011, 279, 87-97. [CrossRef]

80. Cita, M.B. Exhumation of Messinian evaporites in the deep-sea and creation of deep anoxic brine-filled collapsed basins. Sediment. Geol. 2006, 188-189, 357-378. [CrossRef]

81. Joye, S.B.; MacDonald, I.R.; Montoya, J.P.; Peccini, M. Geophysical and geochemical signatures of Gulf of Mexico seafloor brines. Biogeosciences 2005, 2, 295-309. [CrossRef] 
82. Balci, N.; Shanks III, W.C.; Mayer, B.; Mandernack, K.W. Oxygen and sulfur isotope systematics of sulfate produced by bacterial and abiotic oxidation of pyrite. Geochim. Cosmochim. Acta 2007, 71, 3796-3811. [CrossRef]

83. Schippers, A.; Jørgensen, B.B. Oxidation of pyrite and iron sulfide by manganese dioxide in marine sediments. Geochim. Cosmochim. Acta 2001, 65, 915-922. [CrossRef]

84. Canfield, D.E.; Thamdrup, B. The production of 34S-depleted sulfide during bacterial disproportionation of elemental sulfur. Science 1994, 266, 1973-1975. [CrossRef]

85. Thamdrup, B.; Finster, K.; Hansen, J.W.; Bak, F. Bacterial disproportionation of elemental sulfur coupled to chemical reduction of iron or manganese. Appl. Environ. Microbiol. 1993, 59, 101-108. [CrossRef] [PubMed]

86. Pirlet, H.; Wehrmann, L.M.; Foubert, A.; Brunner, B.; Blamart, D.; De Mol, L.; Van Rooij, D.; Dewanckele, J.A.N.; Cnudde, V.; Swennen, R.; et al. Unique authigenic mineral assemblages reveal different diagenetic histories in two neighbouring cold-water coral mounds on Pen Duick Escarpment, Gulf of Cadiz. Sedimentology 2012, 59, 578-604. [CrossRef]

87. Haffert, L.; Haeckel, M.; Liebetrau, V.; Berndt, C.; Hensen, C.; Nuzzo, M.; Reitz, A.; Scholz, F.; Schönfeld, J.; Perez-Garcia, C.; et al. Fluid evolution and authigenic mineral paragenesis related to salt diapirism the Mercator mud volcano in the Gulf of Cadiz. Geochim. Cosmochim. Acta 2013, 106, 261-286. [CrossRef]

88. Harouaka, K.; Eisenhauer, A.; Fantle, M.S. Experimental investigation of Ca isotopic fractionation during abiotic gypsum precitpitation. Geochim. Cosmochim. Acta 2014, 129, 157-176. [CrossRef]

89. Vogel, M.B.; Marais, D.J.; Parenteau, M.N.; Jahnke, L.; Turk, K.A.; Kubo, M.D.Y. Biological influences on modern sulfates: Textures and composition of gypsum deposits from Guerrero Negro, Baja California Sur, Mexico. Sediment. Geol. 2010, 223, 265-280. [CrossRef]

90. Xie, L.; Wang, J.S.; Wu, N.Y.; Wu, D.D.; Wang, Z.; Zhu, X.W.; Hu, J.; Chen, H.R.; Lin, Q. Characteristics of authigenic pyrites in shallow core sediments in the Shenhu area of the northern South China Sea: Implications for a possible mud volcano environment. Sci. China Earth Sci. 2013, 56, 541-548. [CrossRef]

91. Wilkin, R.T.; Barnes, H.L.; Brantley, S.L. The size distribution of framboidal pyrite in modern sediments: An indicator of redox conditions. Geochim. Cosmochim. Acta 1996, 60, 3897-3912. [CrossRef]

92. Rao, V.P.; Kessarkar, P.M.; Patil, S.K.; Ahmad, S.M. Rock magnetic and geochemical record in a sediment core from the eastern Arabian Sea: Diagenetic and environmental implications during the late Quaternary. Palaeogeogr. Palaeoclimatol. Palaeoecol. 2008, 270, 46-52. [CrossRef]

93. Butler, I.B.; Rickard, D. Framboidal pyrite formation via the oxidation of iron (II) monosulfide by hydrogen sulphide. Geochim. Cosmochim. Acta 2000, 64, 2665-2672. [CrossRef]

94. Ohfuji, H.; Rickard, D. Experimental syntheses of framboids-A review. Earth Sci. Rev. 2005, 71, 147-170. [CrossRef]

(C) 2020 by the authors. Licensee MDPI, Basel, Switzerland. This article is an open access article distributed under the terms and conditions of the Creative Commons Attribution (CC BY) license (http://creativecommons.org/licenses/by/4.0/). 